\title{
ARTICLES
}

\section{THE IMPACT OF SOCIO-ECONOMIC STATUS IN LEARNING ENGLISH AMONG CHILDREN OF KAMRUP, INDIA}

Ms. Chitra Sharma* | Dr. Shaifali Rachna Puri**

*Ph.D. Scholar, Himalayan University, Arunachal Pradesh, India.

**Director, Ana Publishing Private Limited, India.

ABSTRACT

DOI: http://doi.org/10.47211/idcij.2020.v07iws02.003

English is contemplated as the most prestigious language on account of its extreme presence in the contemporaneous world. Appreciating the significance of this cosmopolitan language, the administration of India has launched myriad schemes and strategies to learn English even as obligatory. But woefully, the scenario of Kamrup, the capital district of Assam, India is convoluted. Socio-economically needy parents who are normally low-wage workers, indigent peasants, impecunious vendors or peddlers, use to enrol their children to vernacular schools but during flood, the impoverished students have to fight for survival instead of attending schools. Even many government schools remain closed and converted into flood relief camps in flood affected areas. Flood is the burning problem of Assam and the socio-economically necessitous students are the ultimate victims of this disastrous natural calamity. In harvesting time also, the children of poverty-stricken peasants assist their parents in cultivated fields. As a result, they mislay the opportunity to learn English throughout the year. Such parents are not educated enough to embolden their kids in studies, especially in English. They are amateurish to provide sufficient study materials and helpless to fabricate uninterrupted learning atmosphere at home which executes an essential lump in the learning process. This presentation will be beneficial to scrutinize the odds and hurdles of socio-economically backward children while learning English and can expand the path of finding solutions of such challenges.

Key Words: Socio-economy, learning atmosphere and natural-calamity.

\section{ABOUT AUTHORS:}

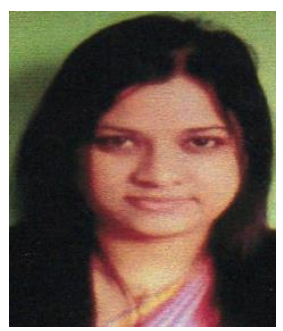

Author Ms. Chitra Sharma is a Ph. D. Scholar in Himalayan University, Arunachal Pradesh, India.

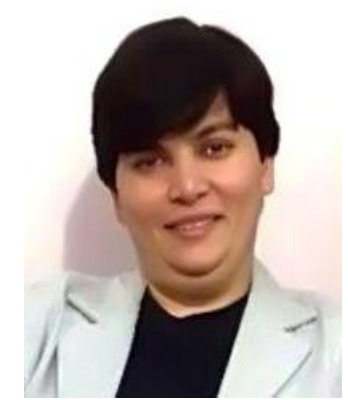

Author Dr. Shaifali Rachna Puri is Director at Ana Publishing Private Limited, India. She has more than twenty five publications to her credit and is a reputed social worker. 


\section{INTRODUCTION}

English is regarded as the most esteemed language on account of its uttermost presence in this new-fangled world. This language is inspected as very instigating. Without learning English no country can imagine to progress in the fields of medicine, business, trade and commerce, communication, media, science and technology and precisely in the field of education. Venerating the importance of this cosmopolitan language, the Indian administration has launched multifarious schemes as well as strategies to assimilate English even as obligatory. But miserably, the scenario of Kamrup, the capital district of Assam in India is convoluted. The socio-economically needy parents normally enrol their children to vernacular medium schools but during flood and harvesting season, the impoverished children have to fight for their survivals instead of attending schools. The poverty-stricken parents are amateurish to provide essential study materials to learn English smoothly at home.

\section{METHODOLOGY}

The Sample Survey Method has been applied to perform the present research. Some vernacular medium schools are surveyed in this study to obtain personal social facts, belief, motivation, approaches and concerns. Questionnaire for the students of vernacular medium schools is used as a research tool.

\section{OBSERVATIONS AND FINDINGS}

The current research is an endeavour to explore the impacts of socio-economy while learning English. The impacts are: -

* Less learned parents.

* Inconvenient learning atmosphere.

* Imperceptible encouragement.

* Irregularity in going to schools.

* Devastating thump of natural calamity.

\section{DISCUSSION}

\section{* Less learned parents}

Socio-economically backward parents are normally the low-wage workers, indigent peasants, impecunious venders or peddlers. They are not educated enough to help their children in learning, especially English. These parents use to send their children to vernacular medium schools where medium of instructions are mother languages. And in the English language classes also, bilingual method is used. As a result, they get little chance to learn English. And at home also, they don't get the opportunity to learn English from their parents.

\section{* Inconvenient learning atmosphere}

Parents, who are economically unsteady, are inadequate to proffer sufficient study materials to their kids. They are amateurish to purchase study utensils like books, pens, pencils, etc. In present times, students can learn English by reading short story books, magazines and by using internet also. But these parents cannot purvey these facilities to their children. They are helpless to fabricate uninterrupted learning atmosphere at home which executes an essential lump in the learning process.

* Imperceptible encouragement

It is known that education is the key to success, and without learning English, it is next to impossible. But impoverished children do not obtain enough impetus from their parents. They hardly encourage their kids to read English short story books, articles, newspapers or to watch educational programmes in TV, obviously telecast in English. They are even not conscious about the education of their children. Because, their whole concentration is on earning bred for their children instead of encouraging them for learning. 


\section{ARTICLES}

\section{* Irregularity in going to schools}

The necessitous children use to vernacular medium schools which have generally high enrolments. But during rainy season and harvesting season the destitute children remain absent from schools, because, they have to struggle for their lives. They have to help their parents or elders in harvesting. Either they assist their parents in paddy fields or study at homes to cook for their elders or took after their siblings, their younger brothers and sisters. These innocent actually want to go to schools but circumstances oblige them for not going to schools in these days. As a result, they miss the opportunity to study English throughout the year.

\section{* Devastating thump of natural calamity}

Flood is the burning problem of Assam. And the impoverished children are the ultimate victims of this devastating natural calamity. During the period of flood, the students of Kamrup, Assam cannot go to schools because they have to fight for survivals. Many of them lose their study materials, some lose their family members and have to come out from their homes because most of their homes are affected by flood water and drown. Now a day, the schools are closed due to COVID 19 pandemic. But this is the common scenario of Kamrup, Assam during flood. Schools remain close in flood affected areas of Kamrup and many schools are converted into Flood Relief Camps. In these crucial days, the flood affected children go to schools not to learn English but to take shelter and food.

\section{CONCLUSION}

English is the language of computers, aeronautics, diplomacy and tourism. Knowledge in English extends the chances of obtaining good jobs in the country or for acquiring assignments abroad. It is very valuable to learn English for socialising raising the economic standard as well as can create many opportunities. This present research will be beneficial to scrutinize the odds and hurdles of socio-economically backward children while learning English. This study can expand the path of finding the solutions of such challenges. This paper can also be helpful for the future scholars to proceed their research in this field.

\section{REFERENCES}

1. Pettigrew, Eydie J., "A Study of the Impact of Socioeconomic Status on Student Achievement in a Rural East Tennessee School System".Electronic Theses and Dissertations.Paper 1844. https://dc.etsu.edu/etd/1844, 2009.

2. Dr. ShrutiAgarwal and Ram Krishan Thakur. "Influence of Environments on the English Learning of Students in India", International Journal on Arts, Management and Humanities, 20 January, 2014.

3. Tulasi Nimmala, 2Pvan Kumar Nowbattula, 3Sundhi Mylabattula, 4Vineela Evan Sodadasi. "SocioEconomic Effects on English Language Learners in Andhra Pradesh". International Journal of Science Technology and Management, Vol. No. 5, Issue No. 08, August 2016.

4. P. Kiatekheere. "Learning Environment for Second Language Acquisition: Through the Eyes of English Teachers in Thailand". International journal of Information Technology, Vol.8, No. 5, May 2018.

\section{Acknowledgement}

I am beholden to my parents, Mr. Krishna Prasad Sharma and Mrs. Tinku Sharma for furnishing continuous support. 